\title{
Revising the Private Placement Exemption
}

Of the exemptions to the general requirement that securities be registered with the Securities and Exchange Commission (SEC) before they are sold to investors, one is especially important: ${ }^{1} \S 4(2)$ of the Securities Act of 1933, ${ }^{2}$ exempting securities which are placed privately rather than through a public offering. In several recent years sales of securities pursuant to $\S 4(2)$ have accounted for over fifty percent of the gross proceeds from new corporate issues. ${ }^{3}$

Securities are privately placed today for a number of reasons, includ. ing substantial cost savings ${ }^{4}$ and the certainty of a firm commitment by the buyers. " Private offerings have become less attractive, however, as the dimensions of the $\S 4(2)$ exemption have become increasingly litigated and uncertain.

The SEC has sought to untangle existing confusion in the area by issuing proposed Rule $146^{6}$ to clarify the requirements of $\S 4(2)$ for

1. The exemptions are generally contained in $\$ \$ 3 \& 4$ of the Sccuritics Act of 1939, 15 U.S.C. $\$ \$ 77 \mathrm{c}$, 77d (1970). See generally L. Loss, Securities Regulation 559.715 (tcmp. student ed. 1961).

2. 15 U.S.C. $\$ 77 \mathrm{~d}(2)(1970)$.

3. See, e.g., SEC, Statistical Bulletin 8 (Oct. 1964); SEC, Statistical, Bulletin 18 (March 1966).

4. In a study conducted in the late 1940's and carly 1950's, the total initial cost of selling debt issues privately was between one-quarter and one-half the cost of a public offering. There were even greater savings for privately-placed equity issucs. L. Loss, supra note 1 , at 693 n.150.

An SEC study of primary common stock issues offered through securities dealers showed that total cost as a percentage of proceeds was 18.5 percent for isstics of less than $\$ 500,000$. The corresponding figure for issues of $\$ 500,000$ to $\$ 1$ million was 14.6 percent. SEC, Cost of Flotation of ReGistered EQuity Issues 1963-1965, at 10 (March 1970). The largest items of expense, except for compensation to dealers, finders and agents, are legal fees, printing costs, and accounting fees. Id. at 59. In a recent study of investments by institutions, the cost factor, particularly for small issues, was found to be a milior reason why issuers sought to avoid public offerings. 5 SEC INSTITUTIONAL INvesrok SIUDY REPORT, H.R. Doc. No. 92-64, 92d Cong., 1st Sess. 2426 (1971) [hereinafter cited it INSTITUTIONAL INVESTOR STUDY REPORT].

Issues are also placed privately by companies whose financial record would make a public offering very difficult. Id. at 2414. Institutions buy many of these issucs, partly due to their ability to diversify their portfolios, their access to investment bankers who seek to sell such issues, and their greater expertise in evaluating these investments. $1 d$. at $2476-77$.

Private placees (those purchasing privately offered securities) benefit by recciving a discount from the market price of the security. The Institutional Investor Stuty Repont showed that the average discount given to private placees was 23.1 percent. Id. at 2153 .

5. An issuer in a private offering is able to obtain a firm commitment from the buyers, thereby fixing price and other terms at the time the negotiations end. In a public offering there is no firm commitment made by the investment batuker placing the offering until just before the offering is made to the public. The issuer is thins exposed to any fluctuations in the market occurring between the time the offering is planned and the time it is actually made to the public. This time interval will often be a number of months. See W. CarY, Corporations 1339.40 (4th ed. 1969).

6. SEC Proposed Rule 146, 37 Fed. Reg. 26137 (1972). The proposed Rule establishes six conditions which, if satisfied, will assure the issuer that the offering will qualify under the $\S 4(2)$ exemption. See pp. 1518-23 infra. 
the initial placement of private offerings. ${ }^{7}$ An alternative proposal for reform of the private offering exemption is contained in the proposed Federal Securities Code. ${ }^{8}$ This Note will argue that neither of these proposals adequately deals with the present problems and will suggest an alternative approach more in keeping with the exemption's basic purpose. ${ }^{9}$

\section{Structure and Problems of Private Placements}

A basic purpose of the Securities Act of 1933 is to compel disclosure of information relevant to the valuation of securities. ${ }^{10}$ Under $\$ 5$ of the Act, ${ }^{11}$ all securities, unless specifically exempted, must be registered with the SEC before they may be offered for sale. The issuer files a registration statement with the SEC, which examines the statement for accuracy and completeness. If the SEC does not object to the statement, the offering may proceed on the condition that investors are provided with a prospectus based on its contents. ${ }^{12}$ The SEC does not pass judgment on the offering's prospects for success; ${ }^{13}$ it only seeks to insure that there has been disclosure of accurate and appropriate information ${ }^{14}$ so that the public's investment decisions may be in. formed. Any person offering or selling securities in violation of $\S 5$ is liable for rescission or damages to each purchaser who took part in the offering. ${ }^{15}$

7. The Commission has previously attempted to provide guidelines for use of the private offering exemption in a series of interpretive releases. Sec, c.g., SEC Securities Act Release No. 5121 (Dec. 30, 1970); SEC Securities Act Release No. 4552 (Nov. 6. 1962): SEC Securities Act Release No. 603 (Dec. 16, 1935); SEC Securities ACt Release No. 285 (Jan. 24, 1935).

8. ALI FED. SEc. Code (Tent. Draft No. 1, 1972) [hercinafter cited as Code], see pp. 1523-26 infra.

9. For other views of the private placement exemption see, e.g., Iandis. The Legis. lative History of the Securities Act of 1933, 28 GEO. WASH. L. REv. 29 (1959); Pation. The Private Offering: A Simplified Analysis of the Initial Placement, 27 Bus. LAw. 1099 (1972); Richardson, The Private Placement Method of Financing, 45 Cur. B.1R REC. 328 (1964); Note, Reforming the Initial Sale Requirements of the Private Placement Exemption, 86 Harv. L. Rev. 403 (1972) [hereinafter cited as Reforming]; Note, $A$ Primer on Prizate Offerings, 24 U. FLA. L. REV. 458 (1972).

10. V. BRudNey \& M. Chirelstein, Corporate Finance 71 (1972).

11. 15 U.S.C. $\$ 77 \mathrm{e}(1970)$.

12. See L. Loss, supra note 1 , at 130 .

13. See SEC, Work of the Securities \& Exchange Commission, in W. Cinx, supra note 5 , at $\mathrm{A}-80$.

14. The information which must be included in a registration statement is listed in Schedule A, 15 U.S.C. \$ $77 \mathrm{aa}$ (1970). Thirty-two items are required, including profit and loss statements, balance sheets, material contracts, projected use of proceeds raised, executive salaries, and capital structure.

15. Section 12(1) of the Act, 15 U.S.C. $\$ 77 l(1)$ (1970). If an issuer offers or sells an unregistered security, its only defense is that the security was excmpt from the regis. tration requirements of $\$ 5$. See note 1 supra. If the issuer is mistaken with regard to the availability of an exemption, each purchaser may recover his investment, with interest, by tendering his security to the issuer, or may seek damages for his losses, if he has already sold the security. 
The $\S 4(2)$ private placement exemption allows issuers the alternative of placing securities in a transaction "not involving any public offering," 16 thus avoiding the registration process of $\S 5$. Yet nowhere in the Act are there criteria defining the circumstances under which the exemption is available: The phrase "not involving any public offering" is never defined.

The legislative history of $\S 4(2)$ provides only limited guidance. In its Report, the House Committee on Interstate and Foreign Commerce noted simply that the exemption would be appropriate where there was "no practical need" for registration or where the "public benefits" resulting from registration would be "too remote." 17 Nevertheless, it seems clear from these words, from the wording of the exemption itself, and from subsequent interpretations by the courts and the SEC that there are two alternative (though not mutually exclusive) views that can be taken of the $\S 4(2)$ exemption.

First, there may be circumstances in which the registration process would be unlikely to provide any significant protection to the investors involved in the offering. Thus, if those to whom the offering is made are in a position to acquire and analyze the requisite information about the issuer, which is essentially what the SEC does during the registration process, registration would be a waste of effort for both the issuer and the government.

This view of $\S 4(2)$ 's purpose, which can be termed the "qualitative approach," is essentially that taken in S.E.C. $v$. Ralston Purina, ${ }^{18}$ the only case in which the Supreme Court has explicitly addressed the definition of private offerings. In that case the Court stated that the reference in the legislative history to "practical need" was "the natural way to interpret the ... exemption . . ."19 Whether the offering is private "should turn on whether the particular class of persons affected needs the protection of the Act." 20 The Court outlined two conditions which would determine the existence of that need: whether the offerees had "access" to registration-type information, and whether they were able "to fend for themselves." 21

Although the Court was vague as to the meaning of the latter phrase, ${ }^{22}$ it has subsequently been taken to mean that the offerees

16. 15 U.S.C. $\$ 77 \mathrm{~d}(2)(1970)$.

17. H.R. Rep. No. 85, 73d Cong., 1st Sess. 5 (1933).

18. 346 U.S. 119 (1953), rev'g 200 F.2d 85 (8th Cir. 1952).

19. 346 U.S. at $124-25$.

20. Id. at 125 .

21. Id.

22. It could be argued that Ralston Purina only requires that the offerees in a private offering have access to registration-type information, and that all the Court meant by 
must be sufficiently sophisticated in financial matters so as to be capable of evaluating the information given them by the issuer. ${ }^{23}$ By the rationale of this requirement, offerees must be sufficiently knowledgeable to insist upon as complete a picture as the SEC would elicit in a registered offering.

Alternatively, an exemption under $\S 4(2)$ might be justified in cases where, although the investors involved could benefit from the protection afforded by the registration process, the limited size of the offering or the limited number of investors involved makes the total potential harm too small to justify the costs of full registration. This "quantitative approach" has found expression in statements of the SEC and in the decisions of a number of lower courts. ${ }^{24}$ Thus, SEC Release $285,{ }^{25}$ issued in 1935 and still relied upon by the courts and the SEC, states that the number of offerees and the size of the offering are factors to be considered in determining whether the exemption is appropriate, ${ }^{26}$ and suggests in particular that an offering involving less than twenty-five offerees will generally qualify for the $\S 4(2)$ exemption. ${ }^{2 \pi}$

These two approaches to the exemption, though not incompatible, are conceptually distinct. If all of the offerees involved are in a position such that they would gain no additional protection from the registration process, then, as the Court suggested in Ralston Purina, there is no need to impose limits on their number, or on the size of the offering. ${ }^{28}$ And conversely, if the number of investors or the size of the

the phrase "able to fend for themselves" was that the offerees must be in a position to obtain this information. Such an interpretation of the opinion is reinforced by the Court's statement at the end of the opinion that an offering to exceutive personncl would be private due to the access they would have to such information. Id. at 125. The case, however, has been interpreted to have established two separate tests.

23. See, e.g., Value Line Fund v. Marcus, [1964-1966 Transfer Binder] CCH FED. SEC. L. REP. If 91,523 at 94, 970 (S.D.N.Y. 1965). The SEC now states that sophistication is the key requirement in private offerings. See p. 1519 infra.

24. See note 27 infra.

25. SEC Securities Act Release No. 285 (Jan. 24, 1935) [hereinafter cited as Release No. 285]. At that time, the private offering exemption was known as clause 2 of $\$ 4(1)$. Section 4 was renumbered by Act of Aug. 20, 1964, Pub. L. No. 88-467 \$ 12, 78 Stai. 580.

26. In addition to these two factors, the Release states that the number of units offered, the manner of the offering, and the relationship of the offerees to each other and to the issuer are to be considered in determining the availability of the excmption.

27. The quantitative approach, and particularly the twenty-five offeree limit, was the generally accepted view of the exemption prior to Ralston Purina. Sec, e.s., Campbell v. Degenther, 97 F. Supp. 975, 977 (W.D. Pa. 1951). See also S.E.C. v. Sunbeam Gold Mines Co., 95 F.2d 699, 702 (9th Cir. 1938); Corporation Trust Co. v. Logan, 52 F. Supp. 999, 1002 (D. Del. 1943). Even after Ralston Purina some courts have continucd to take a predominantly quantitative approach, see Vicisio v. Watson, 325 F. Supp. 1071,1078 (C.D. Cal. 1971). See also Garfield v. Strain, 320 F.2d 116, 119 (10th Cir. 1963); Woodward v. Wright, 266 F.2d 108, 115 (10th Cir. 1959). A more common approach, however, has been simply to combine the qualitative and quantitative criteria, see note 30 infra.

28. In Ralston Purina the SEC sought a ruling from the Court that the exemption would not be available under any circumstances if a substantial number of offerees vere involved. The Court specifically refused to render such an opinion. 346 U.S. at 125. 
offering is so small that the possible benefits from registration would not justify the burdens involved, then there is no need to insist as well that the offerees be in a position such that they would derive no benefits from the registration process. ${ }^{20}$ Nevertheless, the SEC and the lower courts have generally combined the two approaches, requiring both that there be relatively few offerees and that each offeree meet the Ralston Purina standards. ${ }^{30}$

Some limit on the number of purchasers involved in a private offering might, of course, be justifiable even where the purchasers all met the qualitative standards if there were a possibility that the unregistered securities might be rapidly resold to other, less knowledgeable purchasers. Restricting the number of initial purchasers would reduce the chance, and the impact, of such a redistribution. ${ }^{31}$ Yet the SEC and the courts have promulgated a variety of restrictions on the resale of unregistered securities which seem to provide a more effective, and more appropriate, means of dealing with this contingency than do limitations on the size of the initial offering. ${ }^{32}$

29. While the Court in Ralston Purina refused to establish a ceiling on the number of offerees as a matter of statutory interpretation, see note 28 , supra, it did state that the SEC could fix a numerical floor below which the Commission would not investigate the validity of an exemption claim. Id. See also L. Loss, supra note 1, at 661 .

The quantitative approach to private offerings finds an analogy in $\$ 3(\mathrm{~b})$ of the Act, 15 U.S.C. $\$ 77 c(2)(1970)$, which permits the SEC to exempt from the registration requirements public offerings involving less than $\$ 500,000$. An offering under this sec. tion, referred to as a Regulation $A$ offering, need not be formally registered with the SEC, although the regional office of the Commission must be notified ten days in adlvance of the offering. An offering circular must be given to the SEC and to pro. spective purchasers in most cases, and the exemption is not available for ccrtain is. suers. See R. Jennings \& H. Marsh, Securities Regulation 555.77 (3d cd. 1972); L. Loss, supra note 1, at 605-34; E. Thomas, Federal Securities Act Handbook 45.60 (3d ed. 1969).

30. See, e.g., Edwards v. United States, 374 F.2d 24, 28 (10th Cir. 1966) (approving a jury instruction which listed the four factors cited in Release No. 285, supra note 25, adding as a fifth factor "whether the particular persons affected stand in nced of the protection of registration"); Knapp v. Kinsey, 249 F.2d 797, 801 (6th Cir. 1957); Collicr v. Mikel Drilling Co., 183 F. Supp. 104, 112 (D. Minn. 1958) (citing Ralston Purinu and the four factors of Release No. 285).

31. In the Release accompanying proposed Rule 146, see pp. 1520.21 infra, SEC Chairman Casey stated that the reason for including a numerical limit, as well as quali. tative standards, was to "give some assurance that a redistribution of unregistercd securities will not result." Statement of SEC Chairman Casey, Notice of Proposed Rule 146, SEC Securities Act Release No. 5336 (Nov. 28, 1972).

32. Section $4(1)$ of the Act, 15 U.S.C. $\$ 77 \mathrm{~d}(1)(1970)$, denies an exemption for any sale by an underwriter, that is, a purchaser who has bought with a view to distri. bution. A private placement investor must buy for investment and not for distributlon. If not, he will be considered an underwriter and the initial sale to him will invalidate the entire private offering since that sale will have been one step leading to the "distribution" of the securities.

The requirement that private placees buy for investment and not with the intent to resell was developed in a series of cases involving the Crowell-Collicr Publishing Co. Gilligan, Will \& Co. v. S.E.C., 267 F.2d 461 (2d Cir.), cert, denied, 361 U.S. 896 (1959) Crowell-Collier Publishing Co., SEC Securities Act Release No. 3825 (Aug. 12, 1957); Dempsey \& Co., SEC Securities Act Release No. 5690 (May 7, 1958); Elliott \& Co., SEC Securities Act Release No. 5688 (May 7, 1958).

In addition, the potential "spillover" from the sophisticated private investor to the 
Combination of the qualitative and quantitative approaches might also be justified by a lack of faith in the qualitative standards. In that case, however, it would seem more reasonable either to strengthen the qualitative standards or to abandon them entirely in favor of the quantitative approach.

Nor has the needless merging of the quantitative and qualitative approaches proved to be the only difficulty in the administration of the exemption. An additional problem is that the SEC has never attempted to define what constitutes sufficient sophistication on the part of the offeree, or adequate access to information about the issuer, to satisfy the qualitative criteria. Lower courts have been left free to define each of these factors in the way they desire, and the result has been a series of vague and inconsistent decisions. ${ }^{33}$

Furthermore, the SEC and the courts have added a variety of other conditions to the exemption, many of which seem to bear no necessary relation to either the qualitative or quantitative approach. Thus, a "negotiated transaction," ${ }^{44}$ the issuer's use of an investment banker, the relationship among the offerees, ${ }^{36}$ the issuer's relationship with the offerees, ${ }^{37}$ the denomination of the securities sold, ${ }^{38}$ and the party initiating the transaction ${ }^{39}$ have all been considerations employed by various courts and by the SEC in determining the availability of the exemption. ${ }^{40}$

These various problems-the uncritical intermingling of the quali-

general investing public is prevented by SEC Rulc 144, 37 Fed. Reg. 596 (1972). Rule 144 requires purchasers of privately-placed securities to hold them for two years before making a public resale. The issuer must either be a reporting company subject to the requirements of the Securities Exchange Act of 1934 , 15 U.S.C. $\$ \$ 78 \mathrm{~m}, 780$ (d) (1970), or make certain information available on a regular basis. Further, the amount of the securities sold during any six-month period by the private offering purchaser in most cases must not exceed one percent of the outstanding shares of the class to which the security belongs. Rule $144^{\prime} \mathrm{s}$ potential effectiveness is discussed in Note, Resale of $R c$. stricted Securities under SEC Rule 14f, 81 YALE L.J. 1574 (1972) [hereinafter cited as Resale].

33. See, e.g., cases cited note 41 infra.

34. See Release No. 285 , supra note 25 .

35. See SEC Securities Act Release No. 4552 (Nov. 6, 1962).

36. See Garfield v. Strain, 320 F.2d 116 (10th Cir. 1963) (close relationship between issuer and purchasers indicated that the offering was private).

37. See Chapman v. Dunn, 414 F.2d 153, 159.60 (6th Cir. 1969) (defendant's lack of prior acquaintance with investors a factor in holding offering to be public).

38. See Release No. 285, supra note 25 . For an cxcellent discussion of the four factors cited in Release No. 285, and their relationship to the qualitative approach. see Patton, supra note 9, at 1096-1105.

39. See Vicisio v. Watson, 325 F. Supp. 1071 (C.D. Cal. 1971) (fact that investor initiated the transaction a factor in holding offering to be private).

40. In any given case, of course, such factors as these may provide cridence relevant to the issues of sophistication and access to information. Yet the courts and the SEC often seem to view them as independent criteria which must be satisfied in order to qualify under $\$ 4(2)$ regardless of whether or not, in the particular case, they are probative of the offerees' access and sophistication. See Patton, supra notc 9, at 1096-110j. 
tative and quantitative approaches to the exemption, the lack of clear standards for applying the qualitative approach, and the willingness of the courts and the SEC to condition the exemption on additional requirements only remotely related to the function it serves-have combined to create considerable uncertainty among issuers as to the scope of the exemption. ${ }^{11}$

\section{Current Proposals for Reform}

\section{A. SEC Proposed Rule 146}

In an effort to introduce some clarity into the requirements for exemption under $\S 4(2)$, the SEC has recently issued proposed Rule $146 .{ }^{42}$ To qualify for an exemption under the Rule, an offering must meet each of six conditions involving the qualifications of the offerees and their access to information, the number of noninstitutional purchasers, the manner of the offering, precautions against redistribution, and reports to the SEC. The SEC has stated that the Rule is not intended to be the exclusive means of qualifying for the exemption; issuers may choose to comply, in the alternative, with the "relevant administrative and judicial interpretations" in effect at the time of the transaction. ${ }^{43}$

41. The confusion and inconsistency among courts as to the conditions necessary for private offerings is evident in several recent cases. For example, in Lively v. Hirschfeld, 440 F.2d 631 (10th Cir. 1971), rev'g 308 F. Supp. 612 (D. Colo. 1970), the court secmed to create yet another condition by requiring a showing that purchasers were persons of "exceptional business experience" with "regular access to all the information and records which would show the potential for the corporation." $440 \mathrm{~F} .2 \mathrm{~d}$ at 653 . But sec Bowers v. Columbia General Corp., 336 F. Supp. 609 (D. Del. 1971), where plaintiff's motion for a preliminary injunction was denied. The court found that sufficient access was provided, even though "probably not all" the information revealed in a registra. tion statement was available. Id. at 623 . And while others might be more "sophisticatcd" than the investors involved in the case, the court said "[ $t]$ he term must be given a realistic construction, however." $I d$. at 624 .

The SEC itself has added to the confusion by adopting puzzling and secmingly in. consistent positions. In S.E.C. v. Continental Tobacco Co., 463 F.2d 137 (5th Cir. 1972), rew'g 326 F. Supp. 588 (D. Fla. 1971), the offering probably was not private: one of Continental's backers indiscriminately offered the securities to a number of individuals. $463 \mathrm{~F} .2 \mathrm{~d}$ at 151.52. In its brief in the case, however, the SEC also faulted Continental for issuing a prospectus and for updating it. The SEC said that the existence of a prospectus indicated that the offerees were not sophisticated and lacked access. Bricf for Appellant at 29. Yet the SEC itself issued a "no-action" letter where an offering circular was made available to offerees. Walston \& Co., [1971-1972 Transfer Binder] CCH FED. SEC. L. REP. I 78,558 (1971). In its Continental Tobacco brief, the SEC was also critical of the fact that an attorney, who was also a financial adviser, guided a client to Continental. Brief for Appellant at 9. But see Bowers v. Columbia Gencral Corp., supra (citing the employment of attorney and accounting firm as indication that plaintiffs did not need protection of the Act).

42. SEC Proposed Rule 146, SEC Securities Act Release No. 5336 (Nov. 28, 1972), 87 Fed. Reg. 26137 (1972) [hereinafter cited as proposed Rule 146].

43. SEC Securities Act Release No. 5336 (Nov. 28, 1972) [hereinafter cited as Rc. lease No. 5336]. 
Unfortunately, proposed Rule 146 perpetuates many of the problems of the past. To begin with, while the Rule in general follows the qualitative approach to the exemption, and the SEC notes that the nature of the offeree is "perhaps [the] most basic requirement" of the proposed Rule, ${ }^{44}$ no objective criteria are provided for use by issuers when considering the qualifications of prospective offerees. The Rule provides simply that:

[T] he issuer ... shall have reasonable grounds to believe prior to making an offer . . . that either the offeree or his investment representative has such knowledge and experience in financial and business matters that he is capable of utilizing the [available information] to evaluate the risks of the prospective investment and of making an informed investment decision .... .

Thus, the Rule essentially neglects the one difficulty which has previously proved to be the greatest source of confusion under $\S 4(2) .40$

Similarly, Rule 146 does little to clarify the question of access. The Rule requires that the offeree, or his representative, have, or have access to, "the same kind of information that the Act would make available in the form of a registration statement, to the extent such information is available." 17 Strictly construed, this condition would expose issuers to the threat of rescission for failure to comply with every requirement of a public offering prospectus, even though the omission in no way misled the sophisticated purchasers taking part in the offering. ${ }^{4}$ Or, if the provision were more leniently interpreted, an issuer might be found to satisfy the access condition simply by opening its books to offerees, thus giving them "access" to registrationtype information, even though the cost to each offeree of organizing the information in a useable form might be prohibitive. A qualification to the access condition-that information need be provided only

44. Id.

45. Proposed Rule 146(d).

46. The SEC has stated that it will issue interpretive releases under the Rulc. These releases, however, will not be binding on the courts, and thus will not offer the certainty which a definition of sophistication would have if it vere contained in the Rule itself. Further, the interpretive releases presumably will deal with the problems of defining sophistication on a case-by-case basis, and thus will not generate a vorking definition for some period of time.

47. Proposed Rule 146(e).

48. Thirty-two items must be provided in a registration statement. The statement is quite complex to prepare and few statements are acepted by the SEC when they are initially filed. L. Loss, supra note 1, at 273. It seems unreasonable to permit re. scission by sophisticated purchasers in a case where an issuer has failed, e.g., to disclose the terms of a management contract or the exact quantity of outstanding stock options, an outcome which is possible if a court interprets the eregistmation-type information" standard literally. See, e.g., Lively v. Hirschfeld, 440 F.2d 631 (10th Cir. 1971); note 41 supra. 
"to the extent [it] is available"-adds little clarity. Virtually all information is "available" if unlimited time and effort is devoted to compiling it, and thus a court is left with considerable discretion, and an issuer with considerable doubt, as to where to draw the line.

Issuers must also provide "access to any additional information necessary to verify the accuracy of such information" 40 as is required under the Rule. Again, the requirement is exceedingly vague. Strictly construed, it could place an oppressive burden on the issuer, forcing him, for example, to provide verification of every sale he had made. Or, on the other hand, it might be met simply by opening the issuer's books and records to the offerees.

Although Rule 146 emphasizes the qualitative approach to the exemption, it follows past practice by adding as well a quantitative limitation: No more than thirty-five noninstitutional purchasers may be involved, regardless of their sophistication or access to information..$^{50}$ (There may be an unlimited number of institutional purchasers; an institution is defined as any purchaser investing, in cash, a minimum of $\$ 250,000.)^{51}$ As was suggested in Part I, such an approach can prob-

49. Proposed Rule 146(e)(2).

50. The total number of purchasers will be determined over any twelve-month period. The proposed Rule does alter past practice somewhat by permitting an issuer to solicit an unlimited number of suitable offerees, as long as there are not morc than thirty-five noninstitutional purchasers.

In keeping with prevailing doctrine, however, proposed Rule 146 continues to reculure that all offerees, as well as purchasers, meet the other requirements of the Rulc. It has consistently been held that an issuer who offers a security in violation of the Act will be liable to all those who purchased securities during the offering, even though none of the sales violated the Act. See, e.g., Repass v. Rees, 174 F. Supp. 898, 904 (D. Colo. 1959). However, the Act's broad definition of an offer, "every attempt or offer to dispose of, or solicitation of an offer to buy, a sęcurity ..." 15 U.S.C. $\$ 77 \mathrm{~b}(3)(1970)$, leaves issuers uncertain as to what actions can be taken that will not be found to constitute an offer. See, e.g., Chris-Craft Industries v. Bangor-Punta Corp., 426 F.21 569 (2d Cir. 1970) (while SEC Rule 135, 17 C.F.R. $\$ 230.135$ (1970), permitted announce. ments of exchange offers, the conditions of that Rule were violated when the estimated value of the proposed package of securities was included in the announcement, even though the issuer feared that the failure to include such information could cxpose it to liability under the anti-fraud sections, see note 71 infra).

51. The requirement that investments by "institutions" must be in cash is somewhat curious. The aim of this condition may be to prevent a "purchase" on credit, wherc the buyer is actually making several small purchases over a period of time, known as "take-downs," which individually would not qualify for the $\$ 250,000$ cxemption, but which would qualify if viewed as one purchase with a series of installment payments. There seems no reason, however, to prohibit payment in the form of property other than cash as long as it has a fair market value of at least $\$ 250,000$, and, in fact, it is questionable whether "take-downs" themselves should be prohibited. If large purchases are excluded from the thirty-five purchaser limitation because they pose less risk of a redistribution, the risk would not appear to be greatly enlarged if the sale occurs over a limited period of time, e.g., one year.

Another evident problem will be the definition of the "purchaser" that is investing $\$ 250,000$ and thus is not included in the thirty-five purchaser limitation. The SEC has stated that it will not allow unrelated purchasers to act together claiming to be one institutional purchaser. Proposed Rule 146(a)(1)(B). Yet there are legitimate in. vestment clubs, and other bodies such as law firms, which do regularly invest to. 
ably be justified only on the basis of a lack of faith either in the Rule's qualitative standards or in the restrictions on resale of privately-placed securities. ${ }^{52}$ Again, however, it seems that these problems would be more appropriately dealt with by clarifying the qualitative standards ${ }^{53}$ and tightening up the restrictions on resale. ${ }^{\text {th }}$

Following the pattern of previous administrative and judicial approaches to $\S 4(2)$, proposed Rule 146 also imposes a number of additional requirements of dubious relationship to the purposes served by the exemption. Thus the Rule states that the securities must be offered and sold only in a "negotiated transaction" with each offeree. ${ }^{55}$ There is no necessary connection, however, between a negotiated transaction and the need for protection. In many private offerings, the basic terms are decided by the issuer and a few major purchasers. The other purchasers, who may be equally sophisticated and have access to any information they desire, are offered the securities on the terms that have been previously determined. The fact that these purchasers were not involved in the negotiation does not indicate either the absence or presence of sophistication or access; and conversely, the fact that a purchaser was involved in the negotiation of the terms does not necessarily mean that he was sophisticated or had adequate access to information.

In addition, the Rule places an absolute ban on promotional meetings and seminars.50 The intent of this restriction is evidently to bar "boiler-room" sales meetings where issuers engage in a hard sell, seeking to build up enthusiasm without necessarily providing any information about which offerees should become enthusiastic.57 Yet the restriction is too broad, and perhaps entirely unnecessary. The requirement that offerees be sophisticated should prevent them from being taken in by such tactics. Further, seminars and sales meetings may actually increase the chances that an offeree will make an informed

gether. To avoid the problem which arose with the Civil Aeronautics Board's definition of "bona fide" members of charter organizations, 14 C.F.R. \$207.40 (1972), the SEC could require that any group claiming to be an "institutional purchaser" have sub. stantial, e.g., $\$ 250,000$, investments elsewhere.

52. See p. 1516 supra.

53. See pp. 1527-31 infra.

54. There has been some concern that the information available to public purchasers of privately-placed securities is inadequate and that private placces can avoid bearing the economic risks of their investments. See Resale, supra note 32; pp. 1j25.26 infra.

55. The negotiation is to take place directly between the issuer, or its representative (such as an investment banker), and the offeree or his representative. Proposed Rule $146(\mathrm{a})(3)$.

56. Proposed Rule 146(c).

57. See, e.g., S.E.C. v. Continental Tobacco Co., 463 F.2d 137, 143 (5th Cir. 1979); Katz v. Amos Treat \& Co., 411 F.2d 1046, 1050 (2d Cir. 1969). 
investment decision; there would seem to be a greater chance that a prospective investment will be fully examined when there are ten sophisticated offerees questioning management than if each offeree asks questions separately.

Furthermore, the Rule requires that the issuer have reasonable grounds to believe that the offeree "is able to bear the economic risks of the investment." 58 If, as the Rule requires, the offeree (or his representative) is sufficiently sophisticated to be able "to evaluate the risks of the prospective investment," 50 then the offeree himself would seem the most appropriate party to make such a judgment. ${ }^{00}$

Under the Rule, the issuer must take steps to prevent inappropriate redistribution of the securities to the public at large, ${ }^{01}$ and file a report with the SEC after any quarter in which sales have been made pursuant to the Rule.62 The particular measures called for by the Rule are, to be sure, not unreasonable. Yet it would seem more appropriate to impose these requirements on issuers through a separate regulation rather than as a condition for exemption under Rule $146 .^{\circ 3}$ There is little point in making the issuer subject to rescission of the entire of-

58. Proposed Rule 146(d)(2).

59. Proposed Rule 146(d)(1).

60. The Rule's requirement seems quite similar to the suitability rulc which exists with regard to stockbrokers. See 17 C.F.R. \$ $240.15 b 10.3$ (1972); NAtionat. $\Lambda$ ssoc. OF Securities Dealers, Inc., Reprint of the Minual, Art. III, Sec. 2 (CCH cd. 1967). See generally V. Brudiey \& M. Chiretstein, supra note 10, at 1056.79. A leading commentator has suggested that, to be safe, an issuer should believe that the purchaser could afford to lose his entire investment without suffering extreme financial hardship. Goldberg, New SEC Rule 146: An Analysis, 168 N.Y. L.J. No. 10.1, at 1, I (Dec. 1, 1972). This interpretation of the risk requirement, however, would presumably require offerees to disclose their personal financial data to the issuer, including gross income, contents of their portfolio, debt outstanding, and annual cxpenses, beforc a formal offer could be made. Thus the condition may well be unworkable, as well as ambiguous and unnecessary.

61. The proposed Rule requires that the issuer not be aware of circumstances in. dicating that a purchaser is taking the securities with a view to distribution, see note 82 supra, and that the issuer take steps which include placing restrictive legends on stock certificates, giving stop-transfer orders to the transfer agent, and obtaining restrictive agreements from purchasers. Proposed Rule 146(g). The SEC increases uncertainty by stating that the issuer's precautionary measures "shall include but not necessarily be limited to" the above three steps. Release No. 5336. If actions other than these threc steps are viewed as beneficial or necessary, they should at least be made known to issuers.

62. Proposed Rule $146(\mathrm{~h})$. Form 146 requires information concerning the type of security sold, the total dollar amount sold, the price per share, the number of "institutional purchasers," the name of the issuer's representative, and the names of any representatives who acted for purchasers; the form need not be filed by companies selling small amounts of securities nor by those filing periodic reports with the SEC.

63. The SEC could apply appropriate sanctions for violation of any regulations it established: The sanctions could range from consent decrees to an outright prohibition of private offerings by issuers whose conduct was blatantly unlawful. Such regulations conld be issued pursuant to $\$ 19$ of the Act, 15 U.S.C. $\$ 77$ s (1970), which authorizes the SEC to make necessary rules and regulations.

If an issuer sells to a purchaser knowing that the purchaser is taking with a view to distribution, the offering will be invalid under $\S 4(1)$ in any casc, regardless of the use of anti-distribution devices, see note 32 supra. 
fering, at the suit of one of the original purchasers, simply for a technical violation of such requirements. ${ }^{\text {of }}$

It would thus seem that the SEC, in providing the alternative of qualifying for the $\S 4(2)$ exemption either under current law or under Rule 146, has confronted issuers with a Hobson's choice..$^{05}$ The proposed Rule leaves the issuer-and the courts-in precisely the same position as under current law with regard to the difficult issue of determining the qualifications of an offeree to participate in a private offering. And in fact, given the other conditions imposed by the Rulethe ambiguous but seemingly burdensome access requirement, the strict limitation on the number of noninstitutional offerees, the requirement of negotiated transactions, etc.-an issuer might well feel that the current state of the law, for all its difficulties, offers a preferable approach to the exemption.

\section{B. The Federal Securities Code}

A more radical proposal for reform is offered by the tentative Federal Securities Code. ${ }^{\circ 6}$ The Code represents an attempt to revise and recodify the entire body of federal securities legislation. However, it contains an exemption from registration for "limited offerings" 07 which is analogous to $\S 4(2)$, and consequently, even if the Code as a whole were not adopted, its treatment of the private placement exemption could be grafted on to the 1933 Act. ${ }^{08}$

The Code's exemption simply extends to any unadvertised offering for which there are not more than thirty-five noninstitutional investors. Institutional investors, which are defined to include banks, insurance

64. In this respect it should be noted that many issuers of privatcly placed se. curities are small concerns which may simply be unaware of the necessity for taking such measures-even though the offering involved may otherwise be quite suited to the $\$ 4(2)$ exemption.

65. Issuers may in fact find themselves confronted with no choice at all. It scems quite likely that the criteria of Rule 146 will be given substantial weight cren by courts considering private offerings undertaken outside the Rule, and that the dual set of criteria seemingly envisioned by the Rule will nerer desclop.

66. CODE, supra note 8.

67. CODE $\$ 227(\mathrm{~b})$.

68. While the SEC might promulgate a rule using the critcria suggested by the Code, it is possible that the Supreme Court would hold such a rule invalid as conflicting with the legislative intent of $\$ 4(2)$ as interpreted by the Court in Ralston Purina. Although the Court in that case stated that the SEC could, as a matter of general policy, decline to investigate private offerings involving less than some given number of offerees, see note 29 supra, it is not clear that the Court vould permit the SEC to block private civil suits, which would be the effect of a rule, in the case of offerings where neither a qualitative standard nor a limitation on the size of the offering is imposed. Thus it may be that new legislation would be needed to insure the successful adoption of the Code approach. 
companies, registered investment companies, and any other group so denominated by SEC regulations, ${ }^{60}$ may participate in unlimited numbers.

The Code solution has several obvious merits. To begin with, while it contains elements of both the qualitative and quantitative approaches to the exemption, it clearly distinguishes between the two. Institutions are presumed to be financially sophisticated and to be capable of ob. taining access to whatever information they feel is necessary for making an informed investment decision..$^{70}$ On the other hand, with respect to individual investors, the Code abandons any effort to distinguish between those who need the protection of the registration process and those who do not. And, in keeping with the quantitative approach, it simply limits the number of individuals who may participate in the offering. Reliance is placed exclusively on the anti-fraud provisions of the securities acts to protect against serious abuses. ${ }^{71}$

By limiting itself to such simple, objective criteria, the Code entirely avoids the vagueness and uncertainty that has characterized the $\S 4(2)$ exemption to date, and that proposed Rule 146 promises to perpetuate. Yet, at least as it applies to individual investors, the Code procures certainty at a high price. Virtually any issuer, no matter how dubious his scheme, can probably find thirty-five willing investors if he is not limited to individuals with some degree of financial sophistication, or required to disclose to them the details of his business. And, it should be noted, there is no limit to the amount that these thirty-five individuals may be asked to invest. The anti-fraud provisions of the securities acts would, of course, provide a remedy for the worst abuses. Yet the degree of disclosure required by the anti-fraud provisions is unclear, ${ }^{72}$ and thus exclusive reliance on these provisions might leave

69. CODE $\$ 242$. The Reporter states that the SEC is expected to use its rulcmaking powers to put certain classes within the definition of "institutional investor," e.g., large universities, unions, pension funds, and cities, while excluding other classes, e.g., country banks. Id. at $\S 242$, Comment 2. Section 242 of the Code specifically states that factors such as financial sophistication, net worth, and the amount of assets under investment management are to be considered.

70. While institutional investors are presumed to be sophisticated, the elimination of the access condition will remove the leverage which that condition affords to institu. tional as well as noninstitutional investors. The existence of access as a condition of the exemption affords leverage by the explicit threat that the failure to provide access can be a basis for invalidating the entire offering. See pp. 1530-31 infra.

71. The major anti-fraud provisions under current law are $\$ \S 12(2) \& 17$ of the $\mathrm{Act}$, 15 U.S.C. $\$ \$ 77 l(2)$, 77q (1970), and $\S 10(\mathrm{~b})$ of the Securitics Exchange Act of 1984, 15 U.S.C. $\$ 78 \mathrm{j}(\mathrm{b})(1970)$. The degree of disclosure required by these sections, particul. larly $\$ 10(\mathrm{~b})$, is uncertain, 2 A. BRomberc, Securities LAw: Fraud: SEC Rule 10b-5, at 114.8 (1971), but seems to be substantially less than is necessary in a registration statement, id., even though a certain degree of affirmative disclosure is reguired. See, e.g., Steir v. Smith, [1972-1973 Transfer Binder] CCH FED. SEc. L. REr. \$ 93,768 (5th Cir. 1973) (sale of unregistered stock to sophisticated purchaser, subject to the occurrence of a public offering, violated Rule 10b-5 when seller failed to inform buyer of information about the public offering which would have influenced buyer's decision).

72. See note 71 supra. 
investors inadequately protected and issuers uncertain as to their duty. ${ }^{73}$ And in any case, reliance on the anti-fraud provisions will be of little aid to investors who have lost their entire investment if the issuer is judgment-proof, as may well be the case.

In fact, it is not at all clear why any individual investors should be allowed to participate if the sophistication and access requirements are abandoned and there is no limit to the size of the potential losses. While it may be argued that an exception to the qualitative standards is necessary for small issuers, ${ }^{\text {it }}$ the Code's failure to restrict the size of the offering made to individual purchasers would permit any issuer, even those who could afford the cost of registration or seeking out sophisticated purchasers, to take advantage of this exception. The argument that further regulation of offerings involving no more than thirtyfive purchasers would not be justified by the size of the losses that such regulation would prevent seems to disregard the fact that such a group of investors could suffer very substantial losses. ${ }^{\text {to }}$

Another difficulty with the Code approach is that it decreases the protection afforded to members of the investing public who purchase privately-placed securities upon resale. Current law provides such public purchasers with two types of protection. First, since the initial purchasers who bought the securities from the issuer in the private offering presumably had the sophistication and access to information that the law requires, the issue has already been subjected to close scrutiny. Second, initial purchasers of privately-placed securities presently are required to wait two years before reselling, so that they, and not those to whom they subsequently sell the securities, bear the risk that the issuer will quickly fail. The Code, while retaining the requirement for a minimum holding period, ${ }^{70}$ abandons the first form of protec-

73. It is also quite possible that courts would expand the duty to disclose under the anti-fraud provisions if there were no access and sophistication requirements. If this were to occur, the one major asset of the Code-the certainty offered to issuerswould be greatly reduced.

74. Though a number of explanations of the Code have been published, see Loss, Reporter's Introductory Memorandum, in CODE, supra note 8; CODE \$ 227 \& Comments; Loss \& Blackstone, Codification of the Federal Securities Lau's, 28 Bus. LAw. 381 (1973); Loss, The Current Status of SEC Codification, 26 Bus. LAw. 555 (1970): Loss, The American Law Institute's Federal Securities Code Project, 25 Bus. Law. 27 (1969), it appears that the only justification that has been given for permitting an offering to individual investors, without the use of any qualitative standards, is that such an approach is necessary for small issuers, see Reforming, supra note 9, at 417 n.68. Yct even if small issuers do need to be able to offer securities to investors not meeting the qualitative standards, that does not justify the failure to restrict the size of such offerings.

75. The selection of thirty-five as the number of individual investors permitted under the Code seems to have no particular significance. See Loss \& Blackstone, supra note 7f, at 385 .

76. The Code, which proposes to register companies instcad of issues, would permit the initial thirty-five investors to resell to an unlimited number of purchasers one 
tion, and it seems likely that the holding period alone may not be enough. Without an initial analysis by sophisticated, informed inves. tors, the information available in periodic reports after a two-year test period may simply be insufficient to establish the value of the security. ${ }^{77}$ This would be particularly true in the case of new companies where operating losses are often expected and where there is no previous record with which to compare the past two years' performance. In such cases profit and loss statements and balance sheets may not provide a meaningful indication of the company's prospects, while the fact that a group of sophisticated investors provided the seed money for the company, and presently are holding, or selling, their shares may be of great importance to potential public investors.

A modification of the Code approach has been suggested recently whereby noninstitutional investors would sign a waiver stating that they believe themselves to be sufficiently sophisticated and to have received adequate information to make registration unnecessary. ${ }^{78}$ Yet the assumption that the signing of a standard waiver form would offer any real protection to a nonsophisticated investor, while still offering sub. stantial certainty to issuers, is open to serious question. If the SEC and the courts were to accept all such waivers at face value, the waivers would most likely become a mere formality, offering the least protection to those who need it most. Or, on the other hand, if the Commission and the courts were to inquire with care as to whether the waiver was truly knowledgeable, issuers would once again confront the same uncertainty they do now, in each case faced with deciding whether a court might find that a given investor was insufficiently sophisticated to sign an effective waiver. ${ }^{79}$

\section{A Dual Approach}

Although neither the Code nor proposed Rule 146 provides an adequate framework for the private offering exemption, each suggests desirable features for a more workable alternative. A dual approach, providing for distinct qualitative and quantitative exemptions with

year after the initial "limited" offering if, at the time of resale, the isster has been registered with the SEC for one year; if the issuer is not a registered company, unlimited resale is barred for three years. CODE $\$ \S 227(b)(1)(B)$, (b)(2)(A).

77. The inadequacy of the information available in periodic reports is discussed in Resale, supra note 32, at 1582-84. If public investors are not adequately protected under the current system, see id., where private placees must be sophisticated and have access. a fortiori they will not be protected when the private placees may have becn any group of thirty-five investors.

78. Reforming, supra note 9, at 424-26.

79. Cf. Macaulay, Private Legislation and the Duly to Read-Business Run by IBM Machine, the Law of Contracts and Credit Cards, 19 VAND. L. REv. 1051 (1960). 
clear standards for each, would insure both protection for the investing public and a degree of certainty for issuers.

\section{A. Qualitative Standards}

The offeree's ${ }^{80}$ need for the protection of the registration process should remain at the core of the rule. As in proposed Rule 146, the individual investor's access to relevant information, and his ability to analyze that information, should be the criteria upon which his ability to "fend for himself" is judged.81

\section{Sophistication}

In contrast to Rule 146 , however, there should be a relatively clear set of criteria for determining which investors are, and are not, sufficiently sophisticated.

To begin with the rule should clearly state that certain institutions are to be considered sophisticated investors. The Code's definition of an institutional investor seems adequate for this purpose, with the SEC having the power to include or exclude certain classes of institutions. ${ }^{82}$ The definition of an institution given in proposged Rule 146-any investor purchasing more than $\$ 250,000$ worth of securities of the issue in question ${ }^{83}-$ seems less appropriate, since in many cases the amount

80. The rule recommended here will retain the requirement that all offerees, rather than simply purchasers, meet the rule's qualitative standards, see note 50 stupro. While it is true that "it is difficult to see how an offeree who does not buy is hurt," ConE, supra note 8 , at $\$ 227(\mathrm{~b})(\mathrm{l})(\mathrm{A})$, Comment $(2)(\mathrm{b})$, the retention of this requirement vill permit the SEC to act, before anjone is hurt, against an issuer who is soliciting unsuitable offerees.

The SEC should state explicitly that issuers can inquire as to a prospective offeree's suitability without such inquiry being deemed to be an offer. The Release accompanying proposed Rule 146 implied that such action by an issuter would be permitted. See Release No. 5336, supra note 43. Cf. 2 S. Goldegrc, Private Placeinests aid Restricteo Securries $\$ 2.3[b][1]$ (1972). Using its power to define technical terms, 15 U.S.C. $\$$ 7is (1970), the SEC should state that an issuer may provide a general description of a proposed investment, without mention of the price of the security, and may ask a prospective investor to complete a private offering questionnairc, see note 94 infra, without such actions being deemed to be an offer, see note 50 supra.

81. Consistent with the condition that the rule should apply to offerees and not just to purchasers, see note 80 supra, the SEC should require by regulation-but not as a condition of the rule, see pp. $1522-23$ supra; CoDE, supra note 8 , at $\$ 227(b)(1)(1)$, Comment (2)(b)-that no general advertising be undertaken in connection with private offerings. Since general advertising has been held to be an offer to sell, sce, e.g., S.E.C. v. Arvida Corp., 169 F. Supp. 211, 215 (S.D.N.Y. 1958) (furnishing of oral and writicn communications to the press concerning forthcoming public offering held to be offer to sell within $\S 2(3)$ ); S.E.C. v. Chinese Consol. Benev. Ass'n, 120 F.2d 738, 740 (2d Cir. 1941) (advertising in newspapers and soliciting offers to buy Chinese government bonds held to be offer to sell, eren though defendants rcceived no compensation). and as the rule will apply to offerees, such advertising would be inconsistent with a private offering as it obviously would reach offerees not satistying the rule's requirements.

82. See note 69 supra.

83. Proposed Rule 146, while defining institutional investors in terms of size of investment, see p. 1520 supra, does not state that institutions are deemed to be sophisticated; such institutional investors must still meet all the other requirements of 
invested may bear little relation to the investor's sophistication. ${ }^{84}$

The rule should also state that the sophistication requirement is satisfied if the offeree is advised by a sophisticated adviser. For these purposes, a "sophisticated adviser" should include (1) a broker-dealer registered under the Securities Exchange Act of $1934,{ }^{85}$ and (2) an investment adviser registered under the Investment Advisers Act of $1940^{86}$ who has been so registered for five years. ${ }^{87}$ The broker-dealer or investment adviser would be subject to the fiduciary and suitability standards applicable to each, ${ }^{88}$ and would have to be given access to the requisite information about the issuer. ${ }^{\mathbf{8 0}}$

There is much to be said for establishing a sophistication standard

the Rule. Arguably this approach has some justification where, as in Rule 146, inst1. tutions are defined strictly by the size of their investment, but it secms unnccessary where institutions are initially defined in more qualitative terms.

84. See 2 S. GoldBerg, supra note 80 , at $\S 4.1[\mathrm{c}]$. Thus, a major bank may well choose to invest less than $\$ 250,000$ in a given issue, see INSTrTutionsL INvestor Srudy REPORT, supra note 5 , at 2429 (over one-half of equity transactions involving institutional investors involved investments of under $\$ 500,000)$, while a wealthy widow with no in. vestment experience might be talked into placing the bulk of her assets in an tin. reasonably risky venture.

85. 15 U.S.C. $\$ 78 \mathrm{o}(\mathrm{b})(\mathrm{l})(1970)$.

86. 15 U.S.C. $\$ 80 \mathrm{~b}-3$ (1970). Investment advisers must register with the SEC. Registration may be denied, suspended, or revoked for the violation of a number of statutes, and the SEC may seek injufictions to prevent violations of its rules defining fraudulent, deceptive, or manipulative acts or practices.

87. The SEC might also choose to provide that certain other clcarly-defined classes of individuals can act as "sophisticated advisers" in private offerings, such as accountants and lawyers who regularly deal with such matters. The Investment Advisers Act contains a specific provision permitting such individuals to act as adviscrs without registering. 15 U.S.C. $\$ 80 \mathrm{~b}-2(\mathrm{a})(11)$ (1970).

88. Broker-dealers must believe that a security that they recommend to a client is a suitable investment, see note 60 supra, while investment advisers have a fiduciary duty to their clients and may not recommend an investment contrary to their clients needs. See, e.g., Shearson, Hammill \& Co., [1964-1966 Transfer Binder] CCH FED. SEC. L. REP. ๆ 77,306 (1965).

In order to insure in a private offering that the offeree has actually consulted with an adviser, the SEC should require that every investment adviser on whom an offeree is relying sign a form stating that he has examined all information he fecls is necessary in order to make an informed investment decision and that he "has con. sulted with and advised" the offeree in question. The signed form, unless fraud betwcen the issuer and adviser were proven, would conclusively show that the offeree met the sophistication requirement. If the offeree consulted with his adviser, and pur. chased contrary to the adviser's recommendation, the offeree could not claim that he was not sophisticated. Once the offeree has been fully informed of the risks of the investment by an impartial adviser, he is no longer in need of the Act's protection, even though he does not follow his adviser's recommendation.

If the broker-dealer is also serving as the investment banker placing the securitics for the issuer, there would be a potential conflict of interest in his serving as the offeree's adviser. But, contrary to the position taken in proposed Rulc 146(a)(2), the offeree should not automatically be forced to consult with a new adviser, who will not be familiar with the offeree's portfolio, financial objectives, and other pertinent information. If the broker and the offeree have had an on-going relationship, e.g., if the broker has been advising the offeree for a minimum of two years, and the offeree is informed of the potential conflict of interest, the offeree should not be forced to go to a new adviser if he desires to retain his present onc. Presumably if the offerec and adviser have had a continuing relationship, the adviser will be less apt to be unfair with the offeree than if they had had no past dealings and the adviser had no real stake in carefully advising the offeree.

89. See pp. 1530-31 infra. 
which could be satisfied only if offerees are institutional investors or have qualified advisers. The standard would be clear, and most issuers would be able to locate offerees who are within these two classes. ${ }^{30}$ Yet this approach may be too restrictive, since clearly there are investors who meet neither standard yet who are not in need of the Act's protection. Since it is difficult to establish objective standards to apply to such offerees, issuers choosing to deal with individuals claiming to be within this third class of sophisticated investors must necessarily face more uncertainty than when they deal with investors in the first two classes. Nevertheless, it is possible to establish certain standards such investors should meet.

Perhaps the most workable approach is to require that an unadvised individual satisfy two conditions: that he be engaged in an occupation in which he regularly deals with financial matters, and that he have a certain minimal level of investment experience. The first factor, the offeree's knowledge of financing, provides evidence of his ability to analyze and comprehend detailed financial information, and to know what information is most related to an issuer's chances for success. Thus, if he is an accountant, an attorney dealing with corporate finance in the regular course of his practice, or a financial officer of a corporation or a bank, his knowledge of financing could be presumed to satisfy this criterion of sophistication. ${ }^{01}$

Previous investment experience should be a second necessary criterion of sophistication. While it could be argued that only knowledge of financing should be necessary to meet the sophistication standard, familiarity with the valuation of securities and the operation of the stock market are essential qualities of a sophisticated investor, and are most likely to be acquired through actual investment experience. Thus experience in managing ${ }^{22}$ a portfolio of a certain size ${ }^{33}$ over a

90. Of course, even if the class of sophisticated investors were limited to institutions and advised individuals, the alternative quantitative approach to the exemption suggested at pp. 1531-32 infra would still be appropriate.

91. Cf. Hill York Corp. v. American Int'l Franchises, Inc., 448 F.2d 690, 690 (5th Cir. 1971) (corporate attorneys presumed to be sophisticated).

The three occupational groups mentioned need not be the only groups deemed to be sophisticated in financing. The SEC might, for cxample, devclop definitions of professional venture capitalists or full-time investors and consider such individuals as satisfying the occupational requirement. While such classifications are necessarily somewhat ambiguous, courts have been able to find stuch individuals to be sophisticated. See Henderson v. Hayden, Stone Inc., 461 F.2d 1069, 1071 (5th Cir. 1972).

92. Setting a standard for the degrec to which an investor must have participated in the management of his account is a matter of some difficulty. Ideally, the offeree should have either exercised sole responsibility for the portfolio's management or at least have participated in decisions on an equal basis with his broker. However, objective standards of this nature may be impossible to develop. Consequently, it may be necessary to insist simply that the offeree's portfolio not have beenr-managed through a discretionary account with a broker-dealer.

93. The SEC should establish the minimum portfolio size at a level which would insure that the potential offeree has had a moderate amount of investment experience; 
period of years, when combined with the requisite knowledge of financing, would provide a strong indication that the offeree is able to fend for himself..$^{94}$

Obviously neither of these criteria, when taken alone, would be adequate. Many individuals employed in the world of finance may be quite naive about investments, and clearly there are any number of persons who at least nominally manage very large portfolios but have little idea of how to evaluate the prospects for a new securities issue. Yet individuals who satisfy both criteria can be presumed, in general, to be sufficiently sophisticated so that they can invest intelligently without the protection afforded by the registration process. At the same time, the criteria are sufficiently objective so that an issuer can apply them with a fair degree of certainty. Of course, this standard, like any relatively objective standard that might be applied in this area, is somewhat arbitrary. Yet it seems to meet adequately both the issuer's need for certitude and the public's need for protection.

\section{Access}

The access requirement should be retained in order to give sophisticated offerees leverage ${ }^{95}$ in obtaining desired information from issuers. First, issuers should be required to provide offerees with a certain basic amount of information whether or not they explicitly request $i t,{ }^{00}$ and further, they should be required to provide access to any relevant information requested by an offeree.97 The advantage of the first requirement, of course, is that it increases the protection afforded the offeree by relieving him of the need to request even the most basic

the requirement need not be particularly high in light of the occupational standards the offeree must also meet. A portfolio figure in the range of $\$ 25,000$ would secm to be reasonable.

94. In order to implement these proposals, the SEC might develop a standard quics. tionnaire for use by issuers. The form would be similar to that used by broker-deilers when they first interview a new client. See Cohen, The Suitability Rule and Economic Theory, 80 YALE L.J. 1604, 1635 (1971). The form would ask if the offerec is an in. stitutional investor or is being advised by a broker-dealer or a registered investment adviser. If not, it would then inquire as to the offerce's occupation-e.g., whether he is an accountant, corporate attorney, or financial officer-and would ask the offerce whether his portfolio exceeded the established minimum size for the past two ycars and whicther the account was discretionary. The form need not be overly complicated or burden. some, and would prevent purchasers from later denying that they met the sophistication requirements.

95. See note 70 supra.

96. Offering circulars, in which issuers provide basic financial information, are often used by private offering issuers. See, e.g., S.E.C. v. Continental Tobacco Co., 463 F.2d 137, 146 (5th Cir. 1972).

97. The rule should state that an issuer has to provide such additional relcrant information as can be provided "without significant additional expense." The burden would be on the issuer to show either that the information was not relcvant or that it could not be provided without significant expense. 
information, while providing the issuer with some degree of certainty in that, if he meets the given standard, he will be presumed to have complied with the access condition absent a showing that further information was explicitly requested and denied. ${ }^{8}$

The basic information that an issuer should be expected to supply to all offerees need not include every item normally contained in a registration statement. Rather, the standard should probably be similar to that established for a Regulation A offering circular. ${ }^{90}$ Such a circular provides information that will be of interest to almost any investor, while omitting details called for in a registration statement that might be of interest only in particular circumstances or to a small number of potential investors.

\section{B. Quantitative Standards}

In addition to the qualitative standards described above, the SEC should provide that where the size of the offering and the number of purchasers are sufficiently limited, there will be no conditions imposed upon the issuer except that no general advertising may be undertaken. ${ }^{100}$ The rationale for such a provision is simply that, while some of the investors involved might benefit from the protection afforded by the registration process, the total potential losses are too small to justify the costs and risks imposed upon issuers in complying with the stricter qualitative standards. ${ }^{101}$ The restriction on the size of the offering will limit the size of the potential losses-unlike the otherwise

98. Thus, issuers can avoid situations such as that in Lively v. Hirschfeld, 440 F.2d 631, 632 (10th Cir. 1971), where disclosure was found to be inadequate when the issuer only disclosed general corporate information; the plaintiffs aslied for no other information, and thus no information was denied.

99. A Regulation A offering is a small public offering where only a linited registration procedure is required; in most cases, however, issuers must prepare an offering circular to be distributed to offerees. See note 29 supra. The basic infonmation required in a Regulation A offering circular includes: (1) an itemized statement of the purposes for which the proceeds raised are to be used; (2) a briel description of the securities offered; (3) a description of the nature of the isstier's present and proposed products and services; (4) the remuneration of the three highest paid officers and any material contracts held by the officers or directors with the issuer; and (j) a balance sheet as of a date ninety days before the offering, and profit and loss statements for the prior two years. SEC Form 1-A, 1 CCH FED. SEC. L. REP. 7325 (1972). If the issuer does not file reports with the SEC, the financial statements need not be certified.

Unlike an offering under Regulation A, where the offering circular is furnished to the SEC before a public offering is made, an issuer in a private offering would not need to furnish a copy of the offering circular to the SEC; it would not even be necessary for the issuer to prepare a formal circular. The issuer would know, how. ever, that the information contained in a Regulation $A$ offering circular would be the standard with which the information he disclosed would be compared.

100. The ban on general advertising is particularly necessary when there are no other conditions imposed on the offering, since otherwise issuers might contact hundreds of offerees in order to find fifteen naive investors.

101. See pp. 1515-16 supra. 
similar exemption provided for in the Code approach. ${ }^{102}$ And with a limit on the number of purchasers, the average size of the individual investments will increase as the size of the offering approaches the upper limit, thus increasing the chance that the offerees will think it worthwhile to seek advice before investing. ${ }^{103}$

\section{Conclusion}

In commencing to clarify the criteria for $\$ 4(2)$, the SEC has made a considerable contribution. However, the Commission's particular proposal perpetuates many of the problems of the past. The standards suggested here ${ }^{104}$ represent a more suitable substitute for the previous SEC releases that have sown so much dissatisfaction. ${ }^{105}$

102. See pp. 1523-24 supra. The SEC would determine how many purchasers and how large an offering will be permitted under this exemption. Any figures selected must be rather arbitrary. The SEC could, however, determine the total cost of complying with the registration process, with Regulation $A$, and with the qualitative private offering requirements, and decide at what point the costs to issuers do not appear to justify the benefits to investors of imposing stich requirements. While this process is some. what inexact, it is essentially what is done when Congress adjusts the cciling on Regulation A offerings, see L. Loss, supra note 1, at 605.09. In order to restrict the number of investors who could be hurt in such offerings, the number of purchasers should be quite limited. For example, the quantitative exemption might be limited to offerings involving less than $\$ 100,000$ in securities and not more than fifteen purchascrs.

103. This quantitative exemption is particularly appropriate for small closely.held companies where the investors-though perhaps well acquainted with the issucr and its business-cannot satisfy the sophistication standard, where most broker-dealers would not be interested in acting as advisers due to the limited number of investors and size of the offering, and where the issuer cannot afford to prepare even Regulation A-type information.

Thus in the case of small offerings, issuers would have threc alternatives: They could issue the securities publicly and comply with the requirements of $\$ 5$; they could un. dertake a Regulation $A$ offering, which normally would require an offering circular but would allow them to sell to an unlimited number of investors and employ some advertising; or they could undertake a small, private offering, where no offering cir. cular would be required but where there could be only fifteen purchasers and no advertising, and where the purchasers would have to meet the requirements of Rule 144 , note 32 supra, when seeking to resell the securities.

104. The rule proposed above need not be exclusive, though if adopted it would, by offering a clearly discernible "safe harbor," probably become the dominant ap. proach to the exemption. Issuers seeking to place securitics under $\$$ \$(2) outside of the rule would have to rely upon court decisions and any further administrative in. terpretations offered by the SEC.

105. Including, in particular, Releases Nos. 285, supra notc 25, and 4552, supra notes 32,35 , which seem particularly misdirected. 